\section{Justyn Krzysztof Berus OFM}

Uniwersytet Mikołaja Kopernika w Toruniu justynberusofm@gmail.com

ORCID https://orcid.org/0000-0002-9335-8807

DOI: http://dx.doi.org/10.12775/BPTh.2021.023
Biblica

et

Patristica

Thoruniensia

14 (2021) 4: 447-469

ISSN (print) 1689-5150

ISSN (online) 2450-7059

\title{
Pobyt św. Jana Apostoła na Patmos według apokryfu "Dzieje Jana pióra Prochora" a freski w narteksie zewnętrznym Monastyru św. Jana Teologa w Chorze na Patmos
}

\section{St. John the Apostle on Patmos in The Acts of John, According to Prochorus and Frescoes in the Outer Narthex of the Monastery of St. John the Theologian in Chora, Patmos}

Streszczenie. Zewnętrzny narteks monastyru św. Jana Teologa na Patmos został ozdobiony różnymi freskami z Pisma Świętego i tradycji prawosławnej. Wśród nich znajduje się 10 fresków ukazujących życie Jana zgodnie z tekstem Dzieje Jana pióra Prochora. Freski powstały w XVIII w. Artykuł opisuje trzy freski ukazujące pobyt Jana na wyspie. Podkreślono ich zgodność ze sposobem ilustrowania stosowanym w kościele prawosławnym. Zwrócono uwagę na oddziaływanie tekstu apokryfu jako swoistego źródła do ich powstania. Główną ideą, którą mają ukazywać, jest zaznaczenie ciągłości obecności chrześcijaństwa na wyspie poprzez monastyr i szczególne, wybrane sposoby życia na wzór św. Jana poprzez życie mnisze. Mają być one również zachętą dla mnichów, że warto iść drogą powołania monastycznego.

Abstract. The outer narthex of the monastery of St. John the Theologian on Patmos is decorated with various frescoes from the Holy Scriptures and the Orthodox tradition. Among them, there are ten frescoes from the $18^{\text {th }}$ century depicting the life of St. John according to the apocryphal textThe Acts of John, According to Prochorus. The article describes three frescoes depicting John's stay on the island, which represent the method of illustration used in the Orthodox Church. Attention is drawn to the impact of the apocryphal writing as a specific source on the creation of frescos. The main idea they are to present is continuity of Christianity on the island through the existence of monastery and a particular way of life, following the example of St. John, represented by 
the life of the monks. The frescos also serve as an encouragement for monks to follow a monastic vocation.

Słowa kluczowe: narteks; Patmos; freski; św. Jan Apostoł.

Keywords: narthex; Patmos; frescoes; St. John the Apostle.

\section{Wstęp}

Monastyr św. Jana, znajdujący się w miejscowości Chora, jest monumentalnym budynkiem wzniesionym w swej zasadniczej bryle pod koniec XI w., który nadal stanowi centrum życia mniszego na wyspie Patmos. Cała nowożytna historia tego miejsca związana jest z obecnością św. Jana Apostoła. Warto zaznaczyć, że o tej obecności, oprócz samej Księgi Apokalipsy $(1,9)$, dają świadectwo pisarze okresu patrystycznego ${ }^{1}$ oraz apokryfy. Z tych ostatnich, cztery dzieła dotyczące Apostoła Jana wspominają o tym fakcie: Dzieje Jana w Rzymie ${ }^{2}$, Passio Iohannis (Pseudo-Melitona), Virtutes Johannis oraz Dzieje Jana pióra Prochora ${ }^{3}$. Ostatnie z wymienionych - Dzieje Jana pióra Prochora (DzJPr) ${ }^{4}$ - są najdłuższym i najdo-

1 A.R. Sikora, Święty Jan Apostoł na wyspie Patmos „z powodu słowa Bożego i świadectwa” (Ap 1,9), s. 45-46. Autor tak pisze: „Najstarszym świadectwem jest tekst św. Klemensa z Aleksandrii (ok. 150 - ok. 220), który mówi o tym, że «Jan wrócił z wygania na Patmos po śmierci tyrana», a więc po śmierci Domicjana w 96 r. Podobnie twierdzi Orygenes (185-254), a Euzebiusz z Cezarei (264-340) wskazuje, że św. Jan był na wyspie za czasów cesarza Domicjana (81-96). Tertulian (ok. 150-160 - 240) z kolei mówi o wygnaniu Jana z Rzymu, a Wiktoryn (ok. 230 - ok. 304) w komentarzu do Apokalipsy pisze o zesłaniu Jana do kopalni lub kamieniołomów oraz o tym, że został on zwolniony po śmierci Domicjana. Wreszcie o zesłaniu na wyspę Patmos pisze św. Hieronim (430) oraz autor syryjskiego apokryfu «Historia Jana»".

2 Dzieje Jana $w$ Rzymie w dwóch zdaniach wspominają pobyt Jana na Patmos: „Natychmiast Jan popłynął na wyspę Patmos, gdzie stał się godny ujrzeć apokalipsę [objawienie?] wypełnienia czasów. Gdy zaś zabito Domicjana, władzę objął Nerwa, który odwołał wszystkich wygnańców”, M. Starowieyski, Dzieje Jana w Rzymie, s. 344n.

3 W języku polskim, dzięki pracy ks. M. Starowieyskiego, z wyżej wymienionych posiadamy w całości przetłumaczone Dzieje Jana w Rzymie i Dzieje Jana pióra Prochora.

4 Takiego tytułu używa w swoim tłumaczeniu na język polski ks. M. Starowieyski, por. s. 346. W dalszej części artykułu będę korzystał ze skrótu DzJPr zastosowanego przez ks. M. Starowieyskiego. 
kładniejszym tekstem opisującym historię pobytu Apostoła na wyspie Patmos ${ }^{5}$. Tekst powstał w języku greckim (i w takim go znamy w kilku wersjach) oraz zachował się w licznych przekładach: arabskim, ormiańskim, etiopskim, gruzińskim, koptyjskim, łacińskim i starosłowiańskim. Nie posiadamy współczesnego, krytycznego wydania tego tekstu. Obecnie dostępne wydanie zostało opracowane przez Teodora Zahna w XIX w. ${ }^{6}$ Z niego korzystał również Marek Starowieyski w swoim tłumaczeniu na język polski, dlatego ono będzie tekstem źródłowym niniejszego artykułu. Autorem DzJPr ma być Prochor, jeden z pierwszych diakonów Kościoła, wymieniany zaraz po Szczepanie i Filipie w Dziejach Apostolskich (por. Dz 6,5) lub jeden z siedemdziesięciu dwóch uczniów Jezusa wysłanych do nauczania, o których pisze św. Łukasz w Ewangelii (por. Łk 10,1.17). Analiza krytyczna tekstu DzJPr wskazuje, że autor jest nieznany, a samo dzieło powstało między V a początkiem VII w., ale $\mathrm{z}$ większym prawdopodobieństwem $\mathrm{w}$ wie$\mathrm{ku} \mathrm{V}^{7}$. Mimo tak późnego datowania, jest bogatym źródłem informacji na temat obecności św. Jana na Patmos, jako, jak się przypuszcza, późniejszy zapis ustnej tradycji.

Przedmiotem niniejszego artykułu będzie przedstawienie wybranych scen z życia św. Jana Teologa (tak św. Jana Apostoła nazywa Kościół Prawosławny), zawartych w Apokryfie Dzieje Jana pióra Prochora i zilustrowanych na freskach znajdujących się w zewnętrznym narteksie Monastyru Świętego Jana w mieście Chora na wyspie Patmos. Celem tej pracy jest zbadanie relacji, jaka zachodzi pomiędzy tekstem apokryfu a freskami. Wykorzystana zostanie metoda Wirkungsgeschichte ${ }^{8}$, która jest szeroko wykorzystywana w egzegezie tekstów biblijnych, ale jej założenia można z powodzeniem zastosować do pracy nad tym apokryfem. Dokument Papieskiej Komisji Biblijnej Interpretacja Pisma Świętego w Kościele z 1993 r. wskazuje na dwa podstawowe założenia związane z metodą historii oddziaływania tekstu. Po pierwsze, tekst staje się dziełem literackim w momencie, kiedy trafi do rąk czytelnika, który daje mu niejako życie i przyswaja go. Po drugie, to przyswojenie dokonuje się w różnej formie (literackiej, artystycznej, teologicznej, ascetycznej i mistycznej), niezależnie czy nastąpi to w sposób indywidualny, czy wspólnotowy. W każdym przypadku ma ono za cel

\footnotetext{
5 Zob. ibidem, s. 346-347.

6 Zob. ibidem, s. 346.

7 Por. ibidem.

8 Por. S. Szymik, Współczesne modele egzegezy biblijnej, s. 119-131.
} 
lepsze zrozumienie samego tekstu źródłowego ${ }^{9}$. Dodatkowo warto zwrócić uwagę na relacje, jakie zachodzą pomiędzy tekstem a jego zobrazowaniem. Kardynał Gianfranco Ravasi pisze o trzech przykładowych modelach: interpretacyjnym, zniekształcającym i przeobrażającym ${ }^{10}$. Nim jednak spojrzymy na nie, omówiony zostanie pobyt Jana na Patmos, a następnie szczegółowo opisane będą freski ukazujące to wydarzenie.

\section{Pobyt św. Jana Apostoła na Patmos}

Wyspa Patmos ${ }^{11}$ leży na Morzu Egejskim będącym częścią Morza Śródziemnego $^{12}$. Badania archeologiczne, prowadzone jednak w ograniczonym zakresie, poświadczają, że Patmos była zamieszkała od okresu Późnego Brązu (3500-2000 r. przed Chr.) aż do czasów rzymskich ${ }^{13}$. Po edykcie mediolańskim (313 r. po Chr.) rozpoczęło się życie religijne i ruch pielgrzymkowy (związany z pobytem św. Jana), a w miejscu świątyni Artemidy powstała najpierw kaplica, a później bazylika poświęcona św. Janowi ${ }^{14}$. Na skutek wojen arabsko-bizantyjskich i ekspansji wyznawców islamu (w tym napadów pirackich), wyspa od VII w. była opustoszała, a zabudowania zostały zniszczone. Taki stan utrzymywał się do momentu przybycia na wyspę Jana Chrystodulosa, uczonego i pobożnego mnicha z Góry Latros w Azji Mniejszej, który otrzymał wyspę od cesarza Aleksego I Komnena (1081-1118) ${ }^{15}$. Po przybyciu osadników, czyli od 1088 r., rozpoczęto budowę Monastyru św. Jana Teologa w miejscu dawnej bazyliki św. Jana. Trwała ona do XII w. i została ukończona już po śmierci Chrystodulosa. Na przestrzeni wie-

9 Papieska Komisja Biblijna, Interpretacja Pisma Świętego w Kościele, s. 16.

10 G. Ravasi, Biblia i wyobraźnia artystyczna, w Nowy leksykon sztuki chrześcijańskiej, s. $143-144$.

11 Niewielka wyspa grecka leżąca we wschodniej części Morza Śródziemnego, należąca do archipelagu Sporady Południowe. Dzisiaj ten archipelag zasadniczo pokrywa się z archipelagiem Dodekanez.

12 Morze Egejskie znajduje się w północno-wschodniej części Morza Śródziemnego, pomiędzy Grecją a Turcją.

13 Por. A. R. Sikora, Święty Jan Apostoł na wyspie Patmos „z powodu słowa Bożego i świadectwa” (Ap 1,9), s. 41-42.

14 Por. ibidem s. 42-44

15 W muzeum znajdującym się w Monastyrze, można zobaczyć dokument cesarski poświadczający tę darowiznę. 
ków monastyr był rozbudowywany i upiększany ${ }^{16}$.W 1999 roku razem z Grotą Objawienia Apokalipsy i zabytkowymi zabudowaniami miasta Chora, został on wpisany przez UNESCO na listę światowego dziedzictwa kultury.

O pobycie na wyspie pisze Jan w Apokalipsie w następujący sposób: „Ja, Jan, wasz brat i współuczestnik w ucisku i królestwie, i wytrwaniu w Jezusie, byłem na wyspie, zwanej Patmos, z powodu słowa Bożego i świadectwa Jezusa" (Ap 1,9) ${ }^{17}$. To zdanie wskazuje, że głównym powodem pobytu Apostoła w tym miejscu jest głoszenie słowa Bożego i świadectwa Jezusa oraz świadectwo o Jezusie ${ }^{18}$. Nie odpowiada jednak na pytanie, czy Jan na wyspie znalazł się dobrowolnie, czy pod przymusem. Pobytem św. Jana na Patmos zajęli się polscy bibliści między innymi: Dariusz Kotecki ${ }^{19}$, Adam Kubiś i Adam Ryszard Sikora. Obecność Jana na wyspie stał się także przedmiotem analiz w wielu komentarzach obcojęzycznych, z których najszerszym jest opracowanie Davida Aune. ${ }^{20}$.

Adam Kubiś podaje osiem różnych powodów pobytu Jana na Patmos:

1. „Jan mógł chcieć głosić Ewangelię na wyspie, ewangelizując jej mieszkańców, czyli głosić słowo Boga i dawać świadectwo o Jezusie";

2. „Jan (być może zmęczony) mógł także szukać odosobnienia na wyspie, by słuchać słowa Boga, poświadczonego przez Jezusa";

3. „Jan mógł udać się na wyspę z powodu przynaglenia ze strony Boga. To przynaglenie mogło pochodzić zarówno ze słuchania słów Boga, jak i ich studiowania";

4. „Jan udał się na wyspę, aby tam w ciszy i odosobnieniu spisać i edytować wcześniej otrzymane wizje";

5. „W końcu, Jan mógł dobrowolnie uciec na wyspę w celu uniknięcia represji ze strony nieprzychylnych chrześcijanom władz";

6. „Jan, skazany na śmierć, zamiast egzekucji wybrał zesłanie”;

7. „Jan mógł także zostać przymusowo zesłany na wyspę z powodu głoszenia słowa Boga i świadectwa o Jezusie";

8. „Jan znalazł się na wyspie dla otrzymania specjalnego objawienia"21.

16 Por. A. Nikitaras, Guida al Santo Monastero dni San Giovanni il Teologo di Patmos, s. 13-32.

17 Cytaty z Pisma Świętego zostały zaczerpnięte z V. wydania Biblii Tysiąclecia.

18 Zob. A. Kubiś, Patmos, s. 135.

19 Zob. D. Kotecki, Duch Święty w zgromadzeniu liturgicznym w świetle Apokalipsy św. Jana, s. $49-52$.

20 Zob. D. Aune, Revelation, s. 76-80.

21 A. Kubiś, Patmos, s. 136. 
A. Kubiś odnosi się do każdego z powyższych motywów, niektóre odrzuca (pierwszy, drugi i ósmy), inne uważa za mało prawdopodobne (trzeci, czwarty i szósty), piąty warto potraktować poważnie, natomiast za najbardziej przekonujący uważa powód siódmy ${ }^{22}$. Argumenty wskazujące na zasadność siódmej teorii są następujące: po pierwsze użyte słownictwo Apokalipsy w 1,9: „ucisk” i „wytrwałość", po drugie wyrażenia „słowo Boga” i „świadectwo Jezusa” powiązane są w Apokalipsie z cierpieniem (np. 6,9 i 20,4), po trzecie tradycja patrystyczna i apokryfy na to wskazują i po czwarte - początkowa wizja Apokalipsy inspirowana jest wizjami Ezechiela i Daniela - proroków wygnania, zatem Jan - wygnaniec, porównuje się $\mathrm{z}$ tymi prorokami ${ }^{23}$. W tym miejscu można również zastanowić się nad rodzajem kary, którą mógł odbywać św. Jan. Brane pod uwagę są cztery możliwości: (1) zamiana kary śmierci na wygnanie (co jest mało prawdopodobne, ponieważ Jan nie posiadał wysokiego statutu społecznego) ${ }^{24}$, (2) deportatio - wiązało się $\mathrm{z}$ dożywotnim wygnaniem i utratą wszelkich praw (w tym obywatelstwa rzymskiego), (3) relegatio in/ad insulam - wydalenie na wyspę, które mogło być dożywotnie lub czasowe, ale nie wiązało się z utratą obywatelstwa i własności, (4) relagatio ab - dożywotnie lub czasowe wydalenie z terytorium własnego zamieszkania ${ }^{25}$. Pojawia się również jeszcze piąta możliwość - domnatio ad metalla - przymusowa praca w kamieniołomach lub kopalni, która podstawę ma w stwierdzeniu św. Wiktoryna z Petau (zm ok. 304): „Jan był na wyspie Patmos, skazany na kopalnie przez cesarza Domicjana, gdzie widział apokalipsę, którą opublikował po swoim zwolnieniu po śmierci cesarza"26. Była to kara bardzo ciężka, porównywana $\mathrm{z}$ karą śmierci, chrześcijanie traktowali ją na równi z męczeństwem (skazani na nią byli m.in. papieże: Klemens I, Kalikst I i Poncjan). Jest jednak odrzucona m.in. przez Adama Sikorę i Craiga Kostera, ponieważ do dziś nie ma żadnych dowodów na istnienie kopalni na wyspie ${ }^{27}$. Najbardziej prawdopodobną karą jest druga lub trzecia, co potwierdzają pisarze

22 Por. ibidem, s. 136-139.

23 Ibidem, s.139.

24 Por. ibidem.

25 Zob. ibidem, s. 140-141.

26 Wiktoryn z Petau, Comm. in Apoc. 10,3. Warto zaznaczyć, że Wiktoryn jest autorem najstarszego zachowanego komentarza łacińskiego do Apokalipsy św. Jana.

27 Prawdopodobieństwa takiej kary nie wyklucza jednak Adam Kubiś (Patmos, s. 141142), pisząc: „Na Patmos istnieją i istniały kamieniołomy, a istnienie rud metali na wyspie oraz ich kopalni wspomniane jest w starych opisach wyspy". 
wczesnochrześcijańscy ${ }^{28}$. Oprócz kary, którą miał otrzymać Apostoł, badacze nie są zgodni również co do osoby cesarza, za którego panowania św. Jan miał udać się na wyspę. Najczęściej wspomina się o Domicjanie, ale ponieważ nie ma żadnych źródeł rzymskich wskazujących na prześladowanie chrześcijan za tego władcy, niektórzy wskazują na czasy cesarza Nerona lub zaraz po jego śmierci ${ }^{29}$. Różne dane podaje się także w kontekście długości trwania pobytu apostoła na wyspie $^{30}$. Mówi się o okresie trwającym 1,5 roku (ta wersja jest najbardziej prawdopodobna), inni wspominają o 5 latach, a jeszcze inni wskazują, że wygnanie mogło trwać nawet i 15 lat $^{31}$.

Dla dopełnienia opisu pobytu Jana potrzeba spojrzenia na tę sprawę z perspektywy DzJPr, które o jego zesłaniu mówią w kontekście kary zasądzonej przez cesarza Trajana na wniosek mieszkańców Efezu ${ }^{32}$. Autor pisze tak:

Cesarz Trajan do rządzących i rządzonych. Mężowie bezbożni, źli i nieczyści, nauczyciele chrześcijan - mówię o Janie i Prochorze - którzy grzeszą codziennie przeciw bogom dobroczyńcom, przebywali wśród mężów oddających cześć bogom. Ponieważ jednak oddalili się od pomocy bogów nakazujemy, by udali się na wygnanie, ponieważ, i jest to najwyższe zło, znieważyli bogów, po drugie pogardzali prawem i nie czcili cesarza. Tym więc nieposłusznym bożym rozkazom nakazujemy zamieszkać na wyspie Patmos, aby tam, wśród wielkiego udręczenia, którego doznają, pamiętali o bogach najwyższych, aby przez to i wszyscy inni się opamiętali. Naszą więc mocą rozkazujemy, aby apostaci Jan i Prochor zamieszkali na wyspie Patmos $^{33}$.

Z tego fragmentu wynika, że powodem miała być działalność ewangelizacyjna Jana i Prochora, a także cuda, których dokonali (np. wskrzeszenia, wypędzenie złych duchów), a zwłaszcza zburzenie świątyni Artemidy. To wszystko uznano za sztuczki magiczne ${ }^{34}$. Tekst wskazuje również na to, że Jan i Prochor zostali skazani na karę deportatio lub relegatio. Ponieważ pisarze wczesnochrześcijańscy

28 Zob. przypis 2.

29 Por. A. Kubiś, Patmos, s. 149-150.

30 Por. ibidem.

31 Por. A. R. Sikora, Święty Jan Apostoł na wyspie Patmos „z powodu słowa Bożego i świadectwa” (Ap 1,9), s. 47.

32 Por. M. Starowieyski, DzJPr, s. 365.

33 Ibidem.

34 Por. ibidem, s. 352-365. 
są bardzo płynni w używaniu nazw tych kar, trudno jest ostatecznie ustalić, na którą skazany został Apostoł. Tekst apokryfu wskazywałby na deportatio, jeśli przyjmie się, że ta kara była zarezerwowana tylko dla cesarza ${ }^{35}$. Natomiast dalsza treść DzJPr wskazuje, że Jan, przez znaki i cuda, jakich dokonał podczas podróży na Patmos, mógł być całkowicie zwolniony przez strażników lub traktowany łagodniej w myśl kary relegatio. To wszystko ukazuje, że apokryf wpisuje się w całą Tradycję Kościoła dotyczącą pobytu Jana Apostoła na wygnaniu.

$Z$ treści DzJPr wynika również, że powód wygnania nie jest istotny, ale istotne jest to, aby Ewangelia była głoszona gdziekolwiek znajdą się uczniowie Chrystusa. Potwierdza to sam św. Jan w następujących słowach skierowanych do Prochora:

Prochorze, dziecko, wiedz, że ta kobieta żąda od nas świadectwa na piśmie, że byliśmy jej niewolnikami $\mathrm{w}$ obecności trzech wiarygodnych świadków. Nie załamuj się więc $\mathrm{w}$ sercu $\mathrm{z}$ tego powodu, ale raczej ciesz się i wesel - to bowiem uczynimy. W ten sposób Bóg da poznać tej kobiecie jak najszybciej, kim jesteśmy. $\mathrm{W}$ tej bowiem godzinie powiedziała do adwokata swoje zdanie i on nakazał jej tak uczynić. Ona teraz szuka świadków i ma przyjść, i wziąć nas, abyśmy na piśmie wyznali, że byliśmy jej niewolnikami. Dziecko, Prochorze, uczyńmy to dzięki, składając Panu ${ }^{36}$.

\section{Opis ikonograficzny trzech fresków mówiących o pobycie na Patmos}

Kiedy wchodzimy do monumentalnego kompleksu budynków monastyru, natrafiamy na dziedziniec, z którego, skręcając w lewo, możemy dostać się do głównego kościoła pod wezwaniem św. Jana Teologa, kaplicy Matki Bożej (najstarsza kaplica) i kaplicy św. Chrystodulosa, w której znajduje się jego grób. W tym miejscu znajdują się również relikwie głowy św. Tomasza i św. Filipa, Apostołów Chrystusa. Wszedłszy do tych miejsc modlitwy, mijamy narteks zewnętrzny, gdzie znajdują się freski związane z postaciami biblijnymi (prorocy, ewangeliści, apostołowie), przedstawiające różne sceny z Pisma Świętego, władców, świętych (m.in. św. Krzysztof), mnichów, w tym także 10 fresków obrazujących życie św. Jana Teologa w oparciu o apokryf DzJPr. Archimandryta Antipas Nikitaras da-

\footnotetext{
35 Zob. A. Kubiś, Patmos, s. 140-141.

36

DzJPr, s. 354-355.
} 
tuje je na XVIII w. ${ }^{37}$ Freski przedstawiają wydarzenia z życia św. Jana w sposób chronologiczny, rozpoczynając swą opowieść od lewej strony, stojąc na wprost wejścia. Pierwszy ukazuje świętych Piotra i Jana, którzy w Świątyni Jerozolimskiej uzdrawiają chromego od urodzenia ( $\mathrm{Dz} 3,1-10)$. Ostatni natomiast ukazuje odejście Apostoła, które zgodnie z DzJPr dokonało się w Efezie ${ }^{38}$. Prawdopodobnie ich autorem jest mnich $\mathrm{z}$ monastyru, którego imię nie zachowało się w pamięci ${ }^{39}$. Obrazy bezpośrednio związane z apokryfem to freski: siódmy, ósmy i dziewiąty. Ukazują one wydarzenia związane z przybyciem Jana na Patmos, pierwszymi cudami, których dokonał, a także relacji z Kynopsem. Nim jednak każdy z nich zostanie szczegółowo opisany w relacji do treści apokryfu, warto spojrzeć na ogólne cechy wspólne dla wszystkich, zwłaszcza, że są wykonane w podobnym stylu i przez tego samego autora.

Warto zwrócić uwagę na fakt, że freski są namalowane z zachowaniem istotnych elementów kanonu ikonograficznego stosowanego w Kościele Prawosławnym $^{40}$. Należy zatem zaznaczyć, że celem nadrzędnym każdej ikony jest ukazanie świętości i spotkania z sacrum Boga. Świadczą o tym gesty, postawa, zajmowana pozycja przez osoby znajdujące się na fresku i zagospodarowanie otoczenia $^{41}$. J. Charkiewicz wskazuje, że w tym kanonie zwraca się uwagę na następujące elementy: (1) światło, (2) oblicze, (3) ciało, gest i ruch, (4) kolor, (5) szaty i atrybuty, (6) czas i przestrzeń, (7) architektura i pejzaż, (8) napisy i (9)

37 Por. A. Nikitaras, Guida al Santo Monastero dni San Giovanni il Teologo di Patmos, s. 38.

38

Zob. DzJPr, s. 407-408.

39 Dnia 22.07.2021 r. autor artykułu przeprowadził rozmowę z jednym z pracowników monastyru, o imieniu Nikolaus, który przekazał tę informację.

40 J. Charkiewicz (O ikonografii Świętych w Prawosławiu, s. 250) tak to opisuje: „Świętość jest zaznaczana w ikonie za pomocą ustanowionego przez Kościół zasad ikonografii, specjalnego języka malarskiego, zwanego kanonem ikonograficznym. Język ten, podobnie jak i samo nabożeństwo chrześcijańskie, kształtował się przed wiele stuleci «mądrością Kościoła, narodów i historii pod łaski pełnym działaniem Świętego Ducha» i ostatecznie sformował się do XII wieku. W takiej też postaci przetrwał do czasów współczesnych. Uznanie tego języka, «jest przeżyciem więzi z całą ludzkością i uświadomieniem sobie, że życie naszych przodków nie było daremne», bowiem "prawda, którą się kierowali, została utrwalona i oczyszczona przez sobór narodów i pokoleń, krystalizując się w kanonie». Zachowanie kanonu ikonograficznego, który "posiada znaczenie ogólnej zasady", przy pisaniu ikon (ikona jest pisana, a nie malowana) pozwala stwierdzić, czy wizerunek jest ikoną, czy nią nie jest».

${ }^{41}$ Por. J. Charkiewicz, O ikonografii Świętych w Prawosławiu, s. 249-251. 
podpis autora ${ }^{42}$. Charakteryzując krótko i ogólnie każdy z tych elementów, należy zwrócić uwagę na następujące cechy, które znajdują się również na omawianych freskach:

1. Światło. Jest to kluczowy element, ponieważ „Bóg jest światłością i nie ma w Nim żadnej ciemności" (1 J 1,5). Stąd w ikonach nie ma cienia i są one całe światłością, ponieważ ukazują świętość Boga i dlatego też ikony przedstawiają dzień w południe, czyli w momencie największej ilości światła. Źródło światła jest wewnątrz ikony. Samo światło przedstawiane jest na trzy sposoby: tło, nimb (w Kościele Zachodnim znany bardziej jako aureola) i asystka (złote lub srebrne promienie) ${ }^{43}$.

2. Oblicze. Bazą czy też punktem odniesienia dla każdej malowanej postaci, jest oblicze Chrystusa, dlatego święci winni być podobni do Jezusa, przez co wyraża się ich uczestnictwo w świętości Boga. Oblicze, nie twarz, jest w centrum ikony. Przedstawione jest jakby ascetycznie, wręcz wysuszone, co ma wskazywać na wewnętrzny dynamizm duszy dążącej do Boga. Chodzi o piękno duszy, nie ciała. Oblicze ma wyrażać również radość. Centralne miejsce w obliczu zajmują oczy, które są szeroko otwarte, duże i żywe, patrzą ponad widza, co wskazuje, że namalowana postać spogląda w duszę, a nie na człowieka. Pozostałe części oblicza mają znaczenie drugorzędne i jak oczy - skierowane są na zewnątrz, tak uszy, usta czy nos mają być ukierunkowane na wewnątrz. Te narządy mają również zmienione, nienaturalne kształty, które wskazują, że święci nie utożsamiają się z pokusami tego świata. Dla nich istotny jest Bóg i świętość. Usta są wąskie, ascetyczne, zamknięte na świat. Natomiast uszy są duże, co wskazuje na słuchanie słowa Bożego ${ }^{44}$. Co do pozostałych elementów Charkiewicz opisuje je następująco: „Czoło jest wysokie i wypukłe, bowiem wyraża mądrość i siłę ducha. Nos jest wydłużony i cienki, podkreśla szlachetność - nie absorbuje on już zapachów tego świata, lecz wonny zapach świata innego. Szyja jest wydłużona, a podbródek energiczny. Policzki często pokrywają głębokie zmarszczki”45.

3. Ciało, gest i ruch. Ciało jest statyczne, co wskazuje na trwanie w pokoju Bożym. Statyczność wskazuje na rezultat, zdobyty cel, a nie drogę, którą

\footnotetext{
42 Zob. ibidem, s. 251-270.

43 Por. ibidem, s. 251-253.

44 Zob. ibidem, s. 254-256.

45 Ibidem, s. 256.
} 
święty musi przejść. Ciało ukazuje już cechy ciała uwielbionego, przemienionego, ubóstwionego. Święci trwają na modlitwie, ich twarze zwrócone są en face lub $\mathrm{w} 3 / 4 \mathrm{w}$ stronę obserwatora. $\mathrm{Z}$ profilu są przedstawione postacie drugoplanowe lub negatywni bohaterowie. Ruch jest ukazany bardzo harmonijnie, bowiem chodzi o statyczność w Bogu. Często ukazany gest wskazuje na najważniejsze przesłanie realizacji słowa, zwłaszcza dotyczy to dłoni. O modlitwie i posłuszeństwie świadczą ręce wyciągnięte w geście deisis. Często ręce są zakryte rękawami, dłonie wręcz całkowicie zasłonięte, co wskazuje na drżenie przed świętością. Jeśli ciało miało jakieś defekty, to na ikonach jest ukazane jako w pełni zdrowe ${ }^{46}$.

4. Kolor. Ma on szczególne znaczenie, ponieważ razem ze światłem określa nastrój ikony i ukazuje świat już przemieniony. Ma charakter względny, ponieważ nie jest sam dla siebie, ale jak pozostałe elementy ikony, ma prowadzić do ukazania świata duchowego przedstawionej osoby. Każdy kolor ma swoiste znaczenie, jednak należy interpretować kolory w kontekście całej kompozycji, a nie pojedynczo. Ciało ma barwę śniadą, ponieważ celem jest ukazanie wewnętrznego piękna ${ }^{47}$. W kolorach znaczenie ma również nasycenie: „przy czym rozrzedzenie wskazuje na nieważkość, ulotność, a niekiedy na duchowość, zaś zagęszczenie wskazuje na trwałość i siłę, ale jest też symbolem głębokich przeżyć. Kontrast kolorystyczny podkreśla, że kompozycja jest zakończona, podczas gdy półtony wskazują na przechodzenie jednego stanu w inny" ${ }^{48}$. Znaczenie konkretnych kolorów zostanie przedstawione podczas omawiania fresków, które są tematem niniejszego artykułu.

5. Szaty i atrybuty. Szaty zachowują swoje ziemskie właściwości i nie mają za zadanie zakrywać świętości, ale ją przedstawiać. Szata jest ułożona harmonijnie i podobnie, jak oblicze, ma ukazywać wewnętrzny pokój i harmonię świętego. Atrybuty natomiast nie są konieczne ${ }^{49}$.

6. Czas i przestrzeń. Przestrzenią ikony jest nieskończoność. Możliwe jest ukazanie kilku scen, które odbywają się w różnym czasie chronologicznym. Stąd postać na ikonie może pojawiać się kilkukrotnie, w konkretnych wydarzeniach. O wyjątkowości stanowi również odwrócona perspekty-

\footnotetext{
46 Por. ibidem, s. 256-259.

47 Por. ibidem, s. 259-260.

48 Ibidem, s. 261

49 Por. ibidem, s. 263.
} 
wa $^{50}$. To zjawisko szczegółowo opisał o. Paweł Florenski ${ }^{51}$, a Charkiewicz tak je wyjaśnia: „Punkt zbieżności linii w ikonie znajduje się nie wewnątrz kompozycji (jak to ma miejsce w malarstwie tradycyjnym), a po stronie widza, tego kto przychodzi celem spotkania innej rzeczywistości. Stąd wrażenie, że osoby wychodzą z ikony i idą na spotkanie widza. Tym samym kompozycja ikony nie zamyka się, a otwiera na nieskończoność i wolność" 52 .

7. Architektura i pejzaż. Architektura nie jest konieczna, ale jeśli się jednak pojawia, to podporządkowuje się całej harmonii ikony. Dlatego może całkowicie różnić się od realnej architektury, ponieważ jej celem nie jest realne przedstawienie, a wskazanie tylko na miejsce dokonanego zdarzenia. Nawet, jeśli pewne wydarzenia odbywały się wewnątrz, to na ikonie i tak są przedstawione na zewnątrz, a architektura zawsze stanowi drugi lub kolejny plan. Ikona bowiem ignoruje prawa jedności czasu i miejsca. Jako drugi plan, architektura zawsze podporządkowana jest osobie na pierwszym planie. Podobnie jest z pejzażem czy zwierzętami pojawiającymi się w ikonie. Wszystko jest podporządkowane harmonii i świętości ukazanej w ikonie ${ }^{53}$.

8. Napisy. Stosuje się je do sprecyzowania osoby świętego, który znajduje się na ikonie ${ }^{54}$. W przypadku omawianych fresków, autor odszedł od tej zasady, ponieważ obok imion znajdują się również opisy wydarzeń związanych z życiem św. Jana. Wskazuje to nie tylko na samą postać Apostoła, ale na szczególne zadania związane z prowadzoną przez Niego działalnością ewangelizacyjną, a także na Boga jako źródło wszelkiej łaski.

9. Podpis autora. Ogólnie się go nie stosuje, ponieważ ikona „nie jest więc dziełem jego twórczości [autora], jego własnością, a wynikiem działania w nim łaski Bożej”55. Autorem jest Duch Święty, a nie człowiek. To tłuma-

50 Zob. ibidem, s. 264-266.

51 Zob. Ibidem: P. Florenski, Ikonostas i inne szkice..., s. 212-230.

52 J. Charkiewicz, O ikonografii Świętych w Prawosławiu, s. 265.

53 Por. ibidem, s. 266-268.

54 Zob. ibidem, s. 267-268.

55 Ibidem, s. 270. Autor w tym miejscu umieszcza również takie zdanie: „M. Quenot wymienia trzy powody nie podpisywania przez ikonografów swoich dzieł: imię autora jest synonimem jego osobowości, która powinna «umniejszać się»”; ikona wykonywana jest według Tradycji i dokumentów, które nie należą do ikonografia, lecz stanowią swojego rodza- 
czy, dlaczego nie jest znane imię autora fresków z narteksu. Współcześnie część greckich ikon jest sygnowana lub podpisywana nie nazwiskiem autora, lecz następująco: „ręką n.” ${ }^{56}$.

W kontekście powyższych zasad istotne jest spojrzenie na omawiane freski z perspektywy ich wykonania zgodnie z owym kanonem. Jak wyżej wspomniano, trzy freski ukazują pobyt św. Jana na Patmos. To, co jest w nich wspólne, to przedstawienie św. Jana, Prochora, demonów, Kynopsa, jak również tłumu ludzi. Dlatego w takiej właśnie kolejności zostanie omówiona każda z wyżej wymienionych postaci.

Święty Jan przedstawiony jest jako starzec $\mathrm{z}$ brodą ${ }^{57}$, odziany w jasną tunikę (na dwóch pierwszych freskach jest ona niebieska, cieniowana $\mathrm{z}$ błękitem i bielą, natomiast na trzecim jest już prawie w całości biała) i czerwony ${ }^{58}$ klawi, czyli „ozdobny pas w postaci wertykalnych pasów, biegnący od barku do dolnego skraju szaty (jest to symbol misji i posłannictwa, ale też znak czystości i doskonałości)" ${ }^{59}$. Kolor biały oznacza światłość, ponadczasowość, radość, czystość i szczęście ${ }^{60}$. Jest to barwa objawienia, teofanii (zwłaszcza tej dokonanej na Taborze) i łaski, a także obecności Ducha Świętego ${ }^{61}$. Kolor niebieski oznacza tajemniczość, a błękit i jego odcienie to kolor nieba, nieskończoności, pokory i czystości ${ }^{62}$. Czerwony „i jego odcienie to symbol młodości i zdrowia, piękna i bogactwa, ale też kolor walki i ofiarności - barwa krwi, przelanej przez mę-

ju własność Kościoła; natchnienie potrzebne do wykonania ikony pochodzi od Świętego Ducha, a nie od ikonografa".

56 Zob. ibidem, s. 270.

57 Zazwyczaj Apostołowie byli przedstawiani jako młodzieńcy, zwłaszcza św. Jan, który uchodził za najmłodszego z grona Dwunastu. W wypadku jednak wyspy Patmos i wizerunków Jana ukazujących jego pobyt na Patmos, przedstawia się go jako starca, Charkiewicz tak to opisuje: „Ewangeliści często przedstawiani są jak siedzą podczas pracy nad Ewangeliami, przy czym Mateusz, Marek i Łukasz we wnętrzach budynków, a Jan w górskiej scenerii wyspy Patmos. Tenże apostoł w gronie innych apostołów z liczby Dwunastu przedstawiany jest jako młodzieniec, zaś w scenie, jak dyktuje apostołowi Prochorowi na wyspie Patmos, jako sędziwy starzec", ibidem, s. 276.

58 Św. Jana w prawosławiu, przedstawia się przede wszystkim w kolorze zielonym, zob. ibidem, s. 262.
59 Ibidem, s. 276.
60 Por. ibidem, s. 261.
61 Zob. ibidem.
62 Zob. Ibidem, s 262 
czenników za wiarę. Jest to więc też kolor miłości, ofiary i altruizmu"63. W wypadku monastyru na Patmos warto zwrócić również uwagę na pewien szczegół dotyczący koloru płaszcza. Otóż klasztor jest miejscem przeznaczonym przede wszystkim dla mnichów. Kolor płaszcza Jana ma wskazywać na jego dziewictwo (zgodnie z tradycją Jan nie miał żony) i poświęcenie, co powoduje, że dla mnichów jest on przykładem całkowitego oddania się Bogu ${ }^{64}$. Dodatkowo w kaplicy Świętego Chrystodulosa znajduje się fresk, na którym założyciel monastyru ubrany jest w czerwony płaszcz o odcieniu i kształcie przypominającym kolor płaszcza św. Jana ${ }^{65}$. Może to sugerować szczególne znaczenie życia poświęconego Bogu, a także ukazywać jedność i ciągłość pomiędzy św. Janem a budowniczym monastyru i mnichami mieszkającymi oraz modlącymi się w tym miejscu.

Apostoł ukazany jest boso i ze złotym nimbem. Kolor złoty symbolizuje wieczność, życie wieczne, wiarę, ale przede wszystkim Światłość świata - Jezusa Chrystusa ${ }^{66}$. W kontekście tych fresków nimb wskazuje przede wszystkim na świętość Jana, bo kolor złoty wskazuje centrum Bożego życia. Dodatkowo od V w. nimb stał się stałym elementem ikonograficznego przedstawiania Apostołów ${ }^{67}$. Oblicze św. Jana jest namalowane zgodnie $\mathrm{z}$ kanonem ikonograficznym.

Święty Prochor ukazany jest jako młodzieniec, w tunice podobnej do św. Jana, natomiast jego klawi jest koloru zielonego. Charkiewicz tak charakteryzuje ten kolor: „Zieleń symbolizuje równowagę, spokój i brak ruchu. Jest to też symbol życia i odrodzenia duchowego, często wykorzystywany w szatach proroków i Jana Teologa, zwiastuna Świętego Ducha" ${ }^{68}$. Prochor posiada również nimb, podobnie jak św. Jan.

Demony ukazane są w kolorze brązowo-czarnym. Brązowy jest kolorem ziemi, tego co ziemskie, przyziemne, natomiast czarny symbolizuje nicość, śmierć, trwogę, chaos, pustkę i otchłań ${ }^{69}$. Jest również kolorem złych duchów. W relacji do bieli lub innych barw ukazuje się jako tajemnica, której ludzki rozum nie

63 Ibidem.

64 Jest to kolejna informacja przekazana przez Nikolausa, zob. przypis 41.

65 Zob. A. Nikitaras, Guida al Santo Monastero dni San Giovanni il Teologo di Patmos, s. 20 (w kaplicy nie wolno wykonywać fotografii, dlatego autor odsyła do pozycji Nikitarasa).

66 J. Charkiewicz, O ikonografii Świętych w Prawosławiu, s. 261.

67 Por. ibidem, s. 279.

68 Ibidem, s. 262.

69 Por. ibidem. 
jest w stanie pojąc ${ }^{70}$. Dodatkowo demony są ukazane jako mniejsze w kontekście pozostałych osób obecnych na freskach. To wskazuje, że w DzJPr ukazane są przede wszystkim jako sługi Kynopsa ${ }^{71}$ i stworzenia nie posiadające pełni Bożej mocy. Dzięki skrzydłom rogomi ogonowi wpisują się w ogólnie przyjęte wyobrażenie złego ducha - upadłego anioła.

Kynops, jako „najczystszy” mieszkaniec wyspy Patmos ${ }^{72}$, mieszka w odosobnieniu $^{73}$ i uważany jest za wielkiego czarownika. $\mathrm{Na}$ freskach przedstawiony jest jako starzec w brązowej tunice.

Tłumy to ludzie różnych stanów i godności, co wyraża się w strojach, które mają założone. Mają również pewne przedmioty w rękach, dzięki czemu można ich utożsamić $\mathrm{z}$ bohaterami apokryfu.

\section{Tekst apokryfu a wyobraźnia artystyczna autora fresków - pytanie o rodzaj relacji}

Jak wspomniano powyżej, pobyt Jana na Patmos ilustrują trzy freski znajdujące się na zewnętrznym narteksie Monastyru Jana Teologa: siódmy, ósmy i dziewiąty. Przedstawiają one następujące wydarzenia: uzdrowienie Apollonidesa i nawrócenie domu Myrona, posłanie przez Kynopsa złych duchów do walki z Janem (fresk 7), walkę Kynopsa z Janem (fresk 8) i zgubę Kynopsa (fresk 9).

Na pierwszym z wyżej wymienionych fresków widzimy siedzących Prochora i Jana, który trzyma w ręce list. Nad nimi, po prawej stronie, znajdują się dwa demony, a dalej za narożnikiem ściany dziewczyna i młodzieniec. Młodzieniec trzyma w ręku list, a dziewczyna ma sakwę ${ }^{74}$. Za kolejnym załamaniem ściany

70 Por. ibidem.

71 DzJPr, s. 383. Na pytanie Jana: „Dlaczego jesteś mu posłuszny?” Zły duch odpowiedział: „Cała moc Satanaela tam mieszka i on się spotyka z wszystkimi przywódcami, a my z nim, i słucha nas Kynops, a my jego słuchamy" - to zdanie uzasadnia, dlaczego złe duchy są przedstawiane jako mniejsze.

72 Tak nazywa go autor DzJPr: I zapytałem najczystszego Kynopsa, s. 371.

73 Miejscem zamieszkania jest Diabelska Góra, która do dzisiaj jest tak nazywana przez mieszkańców wyspy.

74 Te postacie mogą być różnie interpretowane, ponieważ fresk jest zniszczony i trudno rozpoznać, czy chodzi o syna Myrona i jego siostrę (która oferowała bogactwa), czy o Bazylego i Charis, którzy również oferowali majątek za pomoc i wiarę, którą przekazał Jan (DzJPr, s. 376-378). Autor artykułu przychyla się do wersji pierwszej, czyli do Apollonidesa 
(jest to fresk znajdujący się na najbardziej nierównej powierzchni, która jest efektem konstrukcji budynku) widzimy mężczyzn klęczących przed górą, w której znajduje się jaskinia, a w niej człowiek wypuszczający dwa demony. Fresk przedstawia następujące historie $\mathrm{z}$ apokryfu: Uzdrowienie Apollonidesa, nawrócenie domu Myrona ${ }^{75}$, a także Kynops wysyła złe duchy do walki $z$ Janem $^{76}$.

Z pierwszego z tych fragmentów apokryfów dowiadujemy się, że Jan po przybyciu na wyspę trafia do miasta Fora, gdzie zostaje przyjęty przez Myrona i jego dom. Najstarszy syn, dowiedziawszy się o obecności Jana, ucieka z domu i wysyła list, w którym zaznacza, że uczynił to z powodu Apostoła. Jan zostaje uznany za czarownika i gospodarz domu, chcąc wykorzystać swojego zięcia Wawrzyńca, który jest zarządcą wyspy, pragnie zemścić się na Janie i Prochorze. Obaj trafiają do więzienia, gdzie mają być skazani na walki z dzikimi zwierzętami ${ }^{77}$. Podczas rozprawy sądowej Jan daje świadectwo swojej wiary i odwołuje się do prawa, które nie pozwala skazać podejrzanego bez uprzedniego jego przesłuchania. Zanim wróci do więzienia skuty podwójnym łańcuchem, Apostoł napisze list do Apollonidesa, który dostarczy Prochor, a który spowoduje, że syn Myrona zostanie uwolniony z opętania przez złego ducha. Tak to opętanie św. Janowi opisuje sam Apollonides:

Powód mego odjazdu jest następujący: Mój ojciec i moja matka wiedzą o tym: gdy miałem trzy lata i leżałem w łóżku przyszedł do mnie ktoś i wstrząsnąwszy mną obudził mnie. I ujrzałem go: jego oczy były jak latarnie płonące, a twarz jego czarniejsza niż sadza. I rzekł do mnie: «Otwórz usta!» I otworzyłem, a on wszedł w moje usta i wypełnił moje wnętrzności. Od tej pory pouczał mnie o wszystkim, co złe i dobre wydarzyło się w moim domu. I nie tylko o tym, ale każdy kto mnie spotkał, a znajdował się w nieszczęściu, tego pouczałem o przyczynie tego. Skoro więc wszedłeś do mojego miasta, rzekł on do mnie: «Wyjdź Apollonidesie, byś nie zginął marnie: bo ten człowiek jest czarownikiem i chce cię zabić!» I natychmiast wyszedłem, a on pognał mnie daleko od miasta i w żaden sposób nie mogłem powrócić. I mówił do mnie: «Tylko wtedy, gdy Jan zginie, ty będziesz mógł powrócić do domu». I zapytałem najczystszego Kynopsa, a on powiedział mi to samo. Skoro jednak twój uczeń wszedł do miasta, to ów, który we mnie mieszkał, wyszedł ze

i Chryzyppy, ponieważ młodzieniec trzyma w ręku list, a tylko historia jego uwolnienia od złego ducha jest związana $\mathrm{z}$ listem napisanym przez Jana.
75 DzJPr, ss. 370-374.
76 DzJPr, s. 382-384.
77 Por. DzJPr, s. 370 
mnie i natychmiast zostałem uwolniony od wielkiego ciężaru, moje słowa stały się sprawiedliwe i stałem się dobry względem twojego ucznia ${ }^{78}$.

Ta wypowiedź wiele wyjaśnia w kontekście opisywanego fresku. Przede wszystkim Jan nie jest przeciwnikiem ludzi i nie walczy z mieszkańcami wyspy. Apostoł przyszedł, aby ich uwolnić od prawdziwego wroga, którym jest zły duch. W szystko, co czyni św. Jan, czyni mocą Bożą, a nie własną. Poznajemy w tej historii również Kynopsa, który nazywany jest najjaśniejszym, a który przez kontakty ze złymi duchami czynił różne znaki i cuda. $W$ ten sposób manipulował mieszkańcami wyspy (wrócimy do tego motywu przy następnych freskach). Ostatecznie ta historia zakończyła się nawróceniem Apollonidesa, Myrona i całego jego domu, w tym jego córki, a żony namiestnika wyspy, $\mathrm{Chryzyppy}^{79}$. Wspomniane wcześniej postacie, dziewczyna z sakwą i młodzieniec z listem, to dzieci Myrona, które przyjęły wiarę. W tym miejscu warto również zwrócić uwagę, że Jan nigdy nie przyjmował pieniędzy oferowanych mu za zdziałane cuda, wykonaną pracę i głoszenie Ewangelii. Zawsze kazał te pieniądze przekazywać na potrzebujących i ubogich. Jak sam stwierdza: „bogactwa, o których mówiliście, pożyczcie Chrystusowi, jak powiedział sam Chrystus, nasz Bóg: «Kto miłuje, lituje się nad biednym, pożycza Bogu, a On wedle daru odda mu»" (Prz 19,17) ${ }^{80}$. Dlatego wszyscy nawróceni i ochrzczeni przez Jana, pieniądze, które chcieli mu ofiarować jako zapłatę, ofiarują ubogim i potrzebującym ${ }^{81}$.

Drugi fragment zilustrowany na tym fresku nosi tytuł: Kynops wysyła złe duchy do walki z Janem ${ }^{82}$. Początek tej historii znajduje się w opisie zniszczenia świątyni Apollona, której dokonał Bóg po słowach św. Jana ${ }^{83}$. W następstwie tego zniszczenia kapłani świątyni udali się do miejsca pobytu Kynopsa ${ }^{84}$, aby pomógł im w pozbyciu się Jana. Kynops pierwotnie nie zgadza się na opuszczenie swojego miejsca, ale obiecuje pomóc przez wysłanie demonów, które mają pokonać

78 DzJPr, s. 373-374.

79 Por. DzJPr Uzdrowienie Apollonidesa, nawrócenie domu Myrona i nawrócenie Chryzyppy, s. $370-376$.

80 DzJPr, s. 376.

81 Są to m.in.: Myron, Chryzyppa, Bazyli, Chryzos, i inni.

82 DzJPr, s. 382-384.

83 DzJPr, s. 379.

84 Jest to diabelska góra, do dzisiaj tak nazywana przez mieszkańców wyspy Patmos, a także możemy spotkać się z tą nazwą na mapach i w przewodnikach. 
Apostoła. Z treści dowiadujemy się, że pierwszego, jak i drugiego diabła z wyspy wypędza św. Jan, zatem kolejny raz Kynops wysyła dwa demony, aby jeden rozmawiał $z$ Janem, a drugi obserwował, co się wydarzy i to on informuje czarownika, że św. Jan wszystkie duchy złe, wysłane wcześniej, wypędza z wyspy ${ }^{85}$. Stąd na fresku widzimy dwa demony, co ma ukazywać, że Kynops kilkukrotnie wysyłał złe duchy do Apostoła Jana.

Cała sytuacja opisana wyżej spowodowała wielką złość Kynopsa. Z apokryfu dowiadujemy się, że zebrał wielką liczbę złych duchów, pozostawił ich za murami, a sam z trójką wszedł do miasta, które „całe napełniło się jego głosem, bo nigdy dotąd jeszcze do niego nie wszedł. I zbiegli się do niego i oddawali mu cześć, a on każdemu odpowiadał wedle prośby" ${ }^{\text {"6 }}$. W odpowiadaniu ludziom pomagały Kynopsowi złe duchy, te trzy, które zabrał ze sobą i które biegały do pozostałych (pozostawionych za murami miasta), aby tam zyskiwać potrzebne odpowiedzi. Całe to zachowanie miało być przeciwwagą dla nauczania Jana, który przez dziesięć dni pozostawał w domu Myrona. Po tych dniach wybrał się na miejsce zwane Botrys, aby nauczać. Tam doszło do konfrontacji Jana z Kynopsem. Czarownik korzystał z pomocy złego ducha, aby wyprowadzić z morza ojca utopionego przez pewnego chłopca, a także przywrócić do życia innego, który został zabity z zazdrości. Celem wszystkich działań było pokonanie Jana poprzez znaki, których to jakoby nie potrafił uczynić. Jan swoją postawą pokazuje jednak, że nie robią na nim wrażenia żadne diabelskie sztuczki, a nawet wypowiada bardzo istotne zdanie: „Nie posłał mnie Chrystus wskrzeszać umarłych, ale posłał mnie pouczać ludzi błądzących" ${ }^{87}$. Historia, opisana w podrozdziale Walka Kynopsa $z$ Janem $^{88}$, zilustrowana jest na kolejnym, znajdującym się na łuku sklepienia, ósmym fresku. Po prawej stronie widzimy Kynopsa z tłumem ludzi, który wskoczywszy do wody wyprowadza „wskrzeszonego” chłopca. Po lewej natomiast widzimy św. Jana i Prochora obserwujących całe to wydarzenie. U dołu znajduje się kościółek. Ma to szczególne znaczenie w kontekście zlokalizowania miejsca tego wydarzenia, ponieważ do dnia dzisiejszego, w miejscu, gdzie Jan miał nauczać i chrzcić (zgodnie z tradycją), znajdują się ruiny bazyliki z I w., a także dwa kościoły: pierwszy św. Jana i drugi świętych Polikarpa i Antypasa. Do dzisiaj także ta część miasteczka nazywa się Botras lub Votras.

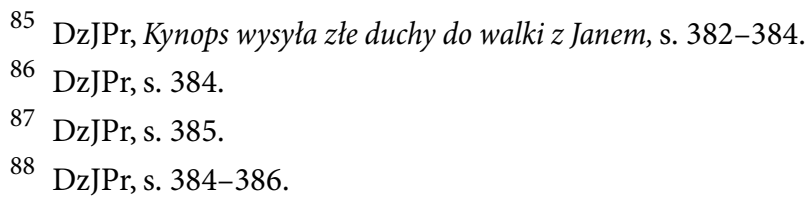


W ostatniej wnęce znajduje się dziewiąty fresk, który obrazuje wydarzenia opisane w kolejnym podrozdziale apokryfu, zatytułowanym: Zguba Kynopsa. Fresk w górnej części ukazuje Jana modlącego się razem z Prochorem. Ten gest jest odzwierciedleniem modlitwy, jaką zanosił do Boga Mojżesz, ponieważ Jan ma rozłożone ręce ${ }^{89}$ i wypowiada następujące słowa: „Panie Jezu Chryste, który sprawiłeś, że Mojżesz dzięki temu znakowi zwyciężył Amalekitów, pogrąż Kynopsa w głębinach morza, aby już nigdy nie ujrzał słońca i by nigdy nie ujrzano go wśród ludzi żyjących"90. Nad Janem i Prochorem widać również rękę Boga, która wskazuje, że wszelkie czyny i cuda czynione przez Jana są dziełem Boga, a także na to, że modlitwa Jana zostanie wysłuchana. W centrum widzimy Jana stojącego nad brzegiem morza, za nim tłum ludzi i Kynopsa unoszącego się na morskich falach. „Najjaśniejszy” wygląda jak martwy. Jan natomiast wskazuje na niego prawą ręką. Kynops został spetryfikowany i już nigdy nie powrócił na Patmos $^{91}$, zgodnie ze słowami Apostoła. Na mozaice widzimy również dwa demony. Są to złe duchy, które usługiwały Kynopsowi i które po zniknięciu swego pana, zostały przez Jana wypędzone $\mathrm{z}$ wyspy. $\mathrm{Z}$ tekstu dowiadujemy się także, że ludzie, nim zabiją Jana (chcieli tego dokonać, ponieważ usunął ich idola), postanowili czekać na powrót Kynopsa. To czekanie trwało trzy dni i trzy noce, i dla niektórych z nich zakończyło się śmiercią (DzJPr mówią o trzech zmarłych osobach). Wtedy Jan zlitował się nad nimi i pomodlił się do Boga, który przywrócił ich do życia. Wtedy ludzie padli na kolana i oddawali cześć Bogu, a także pragnęli słuchać słów Apostoła, który jednak nakazał im powrócić do domów, posilić się i odpocząć. Byli bowiem wycieńczeni. Sam udał się do domu Myrona, gdzie odpoczął i nabrał sił. Następnego dnia przybyło do Jana prawie całe miasto. Mieszkańcy zaczęli Apostoła nazywać bogiem i chcieli oddawać mu cześć, podobnie jak Kynopsowi. Św. Jan, w odpowiedzi na takie zachowanie tłumu, rozdarł swe szaty, posypał głowę popiołem i wszedł na dach. Tłum trwał w ciszy, kiedy Apostoł nauczał ich, że to nie on dokonał tych cudów, ale że sprawcą wszystkiego jest Bóg. Apostoł wskazywał następnie drogę do Jezusa

89 Por. Wj 17, 11. W epoce patrystycznej rozłożone ręce uważano za znak Chrystusa zob. DzJPr przypis 264, s. 387.

90 DzJPr, s. 387.

91 Do dziś w miejscu zniknięcia Kynopsa znajduje się skała na dnie morza (ok. 4 m pod poziomem wody), która swym kształtem przypomina leżącego człowieka. Obecnie nad nią znajduje się boja ostrzegawcza dla statków, ponieważ próby pozbycia się skały kończyły się porażką. Nawet próby jej wysadzenia nie przyniosły oczekiwanych rezultatów. 
poprzez Mojżesza i Proroków. Ostatecznie dowiadujemy się z tekstu, że trzydzieści osób przyjęło chrzest ${ }^{92}$. Zwój w lewej ręce Jana jest ukazaniem prawa Bożego o którym Apostoł wspomina w nauczaniu. Może również wskazywać na tekst dla wierzących, o którego napisanie poproszono Apostoła Jana w momencie decyzji o Jego powrocie do Efezu ${ }^{93}$ lub list, który wysłał, aby wypędzić złego ducha z Apollona. Ta kwestia jest trudna do rozstrzygnięcia. Na fresku, w lewym narożniku, znajduje się również mały kościółek, ten sam co na fresku poprzednim.

Oglądając freski na ścianach narteksu, bez cienia wątpliwości można stwierdzić, że ich autor bardzo dobrze znał tekst DzJPr i na jego podstawie, zgodnie z własną interpretacją, zobrazował pobyt Apostoła na wyspie.

Zgodnie z zapowiedzią dokonamy teraz wyboru modelu interpretacyjnego wykorzystanego przez autora fresków, jednego z trzech proponowanych przez kard. Ravasiego.

Pierwszy z tych modeli to model reinterpretacyjny. Polega on na tłumaczeniu Biblii innymi tekstami Biblii, czyli np. Psalmy 2 i 10, które przemieniają się w pieśni mesjańskie lub psalm 42(43), z informacją o łani pragnącej wody, która jest metaforą lewity lub kapłana wysłanego daleko od świątyni, aby tam mieszkał. Tradycja widziała w tym nie tylko pragnienie bliskości Boga, ale i pragnienie chrztu, i Eucharystii, stąd łania zaspokaja pragnienie na malowidłach wczesnochrześcijańskich w chrzcielnicy lub kielichu eucharystycznym ${ }^{94}$. Model ten również może być rozszerzony aż do współczesności i staje się modelem aktualizującym, w którym motywy biblijne wkomponowane są w krajobraz współczesny autorowi, np. Paul Gauguin w obrazie Wizja po kazaniu umieszcza opowiadanie o walce Jakuba $\mathrm{z}$ Aniołem na rynku bretońskim, wśród niewiast wychodzących ze świątyni ${ }^{95}$.

92 Por. DzJPr: Nawrócenie ludu w Tora, s. 388-389.

93 Tym tekstem, zgodnie z Apokryfem, jest Ewangelia, którą Jan pisał po wcześniejszym poście i modlitwie. Wskazują na to słowa Jana skierowane do Prochora: „ «Dziecko, Prochorze, pisz na kartach papirusu cokolwiek usłyszysz z ust moich!» I otworzywszy swe usta i spoglądając w niebo rzekł: «Na początku było Słowo, a Słowo było u Boga i Słowo było Bogiem. To było na początku u Boga. Wszystko przez Niego się stało, i bez Niego nic się nie stało, co się stało. W Nim było życie, i życie było światłem ludzi, i światło w ciemności świeci, a ciemność go nie ogarnęła» (J 1,1-5). I tak dalej mówił stojąc, a ja pisałem siedząc”. Zob. DzJPr, Powstanie Ewangelii Jana, s. 405.

94 G. Ravasi, Biblia i wyobraźnia artystyczna, w Nowy leksykon sztuki chrześcijańskiej, s. 143. 95 Ibidem. 
Drugim modelem jest model zniekształcający, który opiera się na odchyleniach i deformacji tekstu oraz jego interpretacji, a także lektura tekstu zakłada, że narzędzie hermeneutyczne może być soczewką zniekształconą, jak i zniekształcającą ${ }^{96}$. Również artystycznie tekst biblijny mógł być traktowany odmiennie od pierwotnego znaczenia, a także stawać się pretekstem do stworzenia innego, który może przekształcić jego pierwotne znaczenie. Wtedy otrzymujemy inne znaczenie semantyczne. Przykładem, jak podaje Ravasi, jest Hiob, gdzie sztuka zajęła się ukazaniem tylko pierwszych i ostatnich rozdziałów księgi, przez co stał się przykładem człowieka cierpliwego w momencie doświadczeń. Taki obraz Hioba, człowieka dobrze radzącego sobie w trudnościach, cierpliwego, z dystansem do kobiet, zachował się do dnia dzisiejszego, gdzie pomija się całą treść księg, w której dyskutuje z Bogiem i przyjaciółmi na temat swojego, bolesnego doświadczenia.

Trzecim modelem, znajdującym się na przeciwnym biegunie względem drugiego, jest model przeobrażający. Polega on na tym, że artysta, będąc wierny tekstowi, potrafi „naładować go nieznanymi rezonansami, niejako przepisać go na nowo, ukazując ukryte w nim myśli i pozwalając na ujawnienie się tkwiących w tym temacie nieoczekiwanych możliwości. Nie jest to tylko aktualizacja tekstu, ale przeobrażająca wierność" ${ }^{\prime \prime 7}$. Przykładów takich dzieł jest sporo, dlatego podamy tylko palec wskazujący Boga z fresku Michała Anioła, znajdującego się w Kaplicy Sykstyńskiej, gdzie palec ten zawiera w sobie całe misterium aktu stworzenia, jak zauważa Ravasi ${ }^{98}$, a o którym bezpośrednio nie jest wspomniane w Księdze Rodzaju.

W tym kontekście, interpretując przesłanie fresków z wspomnianego narteksu, należy stwierdzić, że ich autor opierał się na modelu przeobrażającym. Chciał w ten sposób przekazać oglądającym coś więcej niż tylko ilustracje wydarzeń z życia św. Jana. Stwierdzić należy, że przeobraził tekst na potrzeby mnichów i samego miejsca, jakim jest wyspa i znajdujący się na niej monastyr. Stąd ukazanie Jana jako starca w stroju o kolorze takim samym jak strój założyciela. Dobór scen zilustrowanych na freskach również nie jest przypadkowy. Autor wybiera kluczowe postacie i wydarzenia, aby poprzez nawrócenie domu Myrona (jednej z najważniejszych osobistości mieszkającej na Patmos) i pokonanie Kynopsa (sługi szatana i duchowego przywódcy wyspy) ukazać moc Bożej potęgi i Jego

\footnotetext{
96 Por. ibidem.

97 Ibidem, s. 144.

98 Por. ibidem.
} 
panowania nad całym światem. Warto odnotować fakt, że Kynops jest obecny na wszystkich trzech freskach ilustrujących pobyt Apostoła na Patmos, co ukazuje jego pozycję i zarazem wzmacnia znaczenie jego pokonania przez św. Jana. To wszystko pozwala stwierdzić, że najważniejszym powodem powstania fresków było ukazanie jak wielkie znaczenie dla wyspy miało przybycie na nią św. Jana, głoszenie przez niego Ewangelii, udzielanie chrztu i nauczanie mieszkańców. Cuda, które przy tej okazji dokonywał Bóg przez ręce Apostoła, są potwierdzeniem prawdziwości tego nauczania. Dlatego tekst apokryfu, jak i freski mają za zadanie krzewienie i utwierdzanie wiary chrześcijańskiej na Patmos. Wyrazem tego są również następujące wnioski, które odnoszą się zarówno do duchownych jak i świeckich:

1. Permanentne przypominanie mnichom, wchodzącym na modlitwę do kościoła, co jest celem ich pobytu na wyspie: życie poświęcone Bogu i oddawanie Jemu czci, głoszenie Ewangelii, nauczanie ludu i sprawowanie sakramentów.

2. Ukazywanie wiernym i gościom, odwiedzającym wyspę, ciągłość obecności chrześcijaństwa na Patmos od czasów apostolskich do współczesności poprzez monastyr i mieszkających w nim mnichów. W ten sposób obecność mnichów jest również uzasadniona, a oni sami są uważani za duchowych synów i następców św. Jana Teologa.

Podsumowaniem przesłania zawartego w tekście i we freskach są słowa samego św. Jana, który w odpowiedzi udzielonej Myronowi mówi:

Nie posłał mnie Pan, abym siedział spokojnie w domu, ale wysłał mnie do ludzi złych i podłych, o których mówisz. Tak bowiem przykazał nam mówiąc: «Oto posyłam was jak owce między wilki - nie lękajcie się ich». I znowu rzekł do nas: «Przez wiele udręczeń mamy wejść do Królestwa Bożego». Przecież my także mieliśmy domy i dobra, a rzekł nam: «Opuśćcie je i pójdźcie za Mną». I porzuciliśmy wszystko, poszliśmy za Nim. Ja jestem gotów być znieważany z powodu Jego imienia i nie tylko, lecz także umrzeć, być obdartym ze skóry, ale wytrwać, być ściganym, ale nie ustąpić - jednym słowem umrzeć za Jego imię, aby uniknąć wyroku, który dotknie tych, którzy w Niego nie uwierzą ${ }^{99}$.

99 DzJPr, s. 380. 


\section{Bibliografia}

Aune D., Word Biblical Commentary Revelation 1-5, Colombia 1997.

Charkiewicz J., O ikonografi świętych w prawosławiu, „Elpis” 12 (2010) 21-22, s. 245-289.

Kotecki D., Duch Święty w zgromadzeniu liturgicznym w świetle Apokalipsy św. Jana, Warszawa 2006.

Kubiś A., Patmos geografia historia apokryfy, Rzeszów 2021

Nikitaras A., Guida al Santo Monastero di San Giovanni il Teologo di Patmos, Patmos 2014.

Papieska Komisja Biblijna, Interpretacja Pisma Świętego w Kościele, https://biblia.wiara. $\mathrm{pl} /$ doc/423153.INTERPRETACJA-PISMA-SWIETEGO-W-KOSCIELE (dostęp: 6.12.2021).

Ravasi G., Biblia i wyobraźnia artystyczna, w: Nowy leksykon sztuki chrześcijańskiej, red. M. Pieniążek-Samek (redaktor naczelny), Kielce 2013.

Sikora A., Święty Jan Apostoł na wyspie Patmos „z powodu słowa Bożego i świadectwa” (Ap 1,9), w: Benignus est enim spiritus sapientiae. Opuscula Bogdano Ponizy septuagenario dedicata, red. M. Mikołajczak, Poznań: Uniwersytet im. Adama Mickiewicza w Poznaniu. Wydział Teologiczny. Redakcja Wydawnictw 2015 (Opuscula Dedicata), [t.] 9) s. 41-51. Starowieyski M., Apokryfy Nowego Testamentu, tom II: Apostołowie, Kraków 2017. Szymik S., Wspótczesne modele egzegezy biblijnej, Lublin 2013. 